Ágnes Kövér*

\title{
The Relationship between Government and Civil Society in the Era of COVID-19
}

https://doi.org/10.1515/npf-2021-0007

Received February 13, 2021; accepted February 14, 2021

Abstract: COVID-19 created an extraordinary social situation in which governments struggle to mitigate the harmful consequences of the pandemic. Challenging times show a society's resilience and capacity for solidarity and cohesion, the government's ability to deal with emergencies effectively, the stability and inclusiveness of political systems, and their aptitude to respect democratic values. It is particularly important to examine this period from the point of view of civil society and civil society organizations (CSOs), since civil society plays a pivotal role in the alleviation and dissipation of societal troubles associated with the epidemic, indeed a vital role in curbing the virus. The civil sector's strength and resilience too is tested. As the studies in this Special Issue show, exploiting the potential of civil society was an option that only some countries have been able to seize - as a result of which they have effectively reduced the consequences of the calamity while increasing a sense of solidarity and belonging in their societies. Others, however, failed to recognize the importance of civil society and interpreted the situation as a "single-actor play on stage". Neither solidarity nor cohesion play out as values in these latter cases; instead the single actor - government - grabs the opportunity to play the role of the heroic savior and the exclusive problem solver, grabbing for itself both symbolic gains and increasing concentration of power. Citizens are expected to trust no one or no organization except the charismatic leader (or party). Thereby is forged a vertical and hierarchical chain of control, rather than a horizontally linked network of trust and cooperation. The studies and commentaries in this issue cover nine countries located on an imaginary line beginning in the United Kingdom, and extending through Germany, Austria, Hungary, Turkey, Israel, India, China and South Korea, representing various socio-political and economic systems. Embedded in elaborated theoretical understandings, this introductory essay examines the research articles of this Special Issue in which authors unfold the dynamics of CSO-government relations in the context of the world pandemic. These accounts sharpen our understanding of the preexisting shape of government-CSO relations. The introduction places the countries on a scale which classifies them according to the characteristics

*Corresponding author: Ágnes Kövér, Institute of Social Studies, Eotvos Lorand University, Budapest, Hungary, E-mail: kovera@tatk.elte.hu. https://orcid.org/0000-0001-7596-6473 
of civil society-government relations unfolding during the pandemic. One of the endpoints is represented by those countries where the CSO's creative and constructive responses to the social challenges were prevented or blocked by the government. In this setup, CSOs were ignored at best, and restrictions undercut their abilities to contribute to the process of mitigating the pandemic and its consequences. Meanwhile, at the opposite end of this scale, are countries where the government, both central and local, invited civil society partners in the response to COVID-19, orchestrated high-quality and multilevel cross-sectoral cooperation, and provided partners with the necessary (financial) resources. In those cases, CSOs were empowered effectively to participate in a process designed to address the epidemic and its consequences in accordance with principles of participatory democracy.

Keywords: government-civil society (CSOs) relations, world pandemic, autonomy, partnership, solidarity

COVID-19 created an extraordinary social situation in which governments struggle to mitigate the harmful consequences of the pandemic. Countries were instantaneously thrust into isolation from one another while their governments engaged in desperate searches for viable solutions and strategies. Experiencing these events as participating witnesses, including the seemingly endless quarantine and isolation, spurred my colleagues all over the world to share their thoughts and observations via online connections. In doing so, the idea to compose a Special Issue under the auspices of the Nonprofit Policy Forum emerged at the beginning of the Summer of 2020.

The significance of this period in our lives was indisputable, especially when we considered that challenging times serve as a litmus test for the deeply structured nature of different public systems: they show a society's resilience and capacity for solidarity and cohesion, the government's ability to deal with emergencies effectively, the stability and inclusiveness of political systems, and their aptitude to respect democratic values - even in difficult times. It is particularly interesting to examine this period from the point of view of civil society and civil society organizations (CSOs), since civil society plays a pivotal role in the alleviation and dissipation of societal troubles associated with the epidemic, indeed a vital role in curbing the virus. The civil sector's strength and resilience too is tested by challenging times. Whether we speak about civil society in the broadest sense, or narrow our concerns to formalized civil society organizations, these periods of crisis sharply highlight the willingness and capacity of the sector (and of people) to sacrifice, to volunteer, and to assist the weak and vulnerable. The cohesion of society, its well-being and sense of security, is concomitantly forged in this experience. No doubt that there is an enormous potential in civil 
society and CSOs to amplify the efforts of government, especially in an emergency, both national and worldwide.

In times of crisis, the pluralist and social democratic visions that underlie the effective workings of civil society often fade. In some cases, governments overestimate the voluntary financial and physical efforts of the population fighting the virus, utilizing or even abusing the basic value of solidarity. In other cases, governments take advantage of the emergency to further strengthen pre-existing positions, moving ever closer to the elimination of democratic control and advancing authoritarian forms and structures.

As the studies in this volume show, exploiting the potential of civil society was an option that only some countries have been able to seize - as a result of which they have effectively reduced the consequences of the calamity while increasing a sense of solidarity and belonging in their societies. Others, however, failed to recognize the importance of civil society and interpreted the situation as a "single-actor play on stage"1. Neither solidarity nor cohesion play out as values in these latter cases; instead the single actor - government - grabs the opportunity to play the role of the heroic savior and the exclusive problem solver, grabbing for itself both symbolic gains and increasing concentration of power. Citizens are expected to trust no one or no organization except the charismatic leader (or party). Thereby is forged a vertical and hierarchical chain of control, rather than a horizontally linked network of trust and cooperation.

The studies and commentaries in this issue cover nine countries located on an imaginary line between the United Kingdom and South Korea, representing various socio-political and economic systems. Some of them are part of the European Union, namely Germany, Austria, Hungary (though even these are very different from one another), and the United Kingdom, which was about to leave the EU while this Special Issue was being written. The Middle East is represented by Israel, East Asia by China and South Korea, South-Asia by India, and finally Turkey stands in its unique geographic position astride both Asia and Europe.

The endeavor of this volume is to explore and screen the dynamics of government - civil society (CSOs) ${ }^{2}$ relations, as they were unwittingly tested by the pandemic during 2020. Questions central to our interests include: the implicit/ explicit role which civil society played in the process of defense, harm relief, and recovery; the provision of the necessary means to perform these tasks; and the role

1 Bok Gyo Jeong's and Sung-Ju Kim's article in this volume applies this expression.

2 The focus of most writings is the civil society organizations (CSOs) however the extended understanding of civil society is often applied, especially in the case of the South Korean paper, where the latter serves as the frame of reference. 
civil society played, or might have played, in disseminating information and assisting the population.

The studies presented in this issue examine how the epidemic has affected the economy and society in general; they show how deeply the civil sector and CSOs have been hit by the emergency and the consequences of the lockdowns they endured; they introduce and assess the overall government strategies that were employed to fight the epidemic. Government-CSO co-operation is always interpreted in the context of the system on which these relationships are built, and which determine the quality of these relationships during the epidemic. Each study puts the civil society of the concerned country in a different theoretical framework, which persuasively explains the effective, cumbersome, or sometimes uncooperative relations that came to prevail in the emergency. The studies also examine the strategies CSOs developed to adapt to the exceptional situation and they consider their efforts to mitigate the social and human consequences of the epidemic. In most cases, the impact of the epidemic and the lockdowns is also examined.

Most of the studies include empirical research, the results of which are based on data collected in the first wave, and early stages of the second wave ${ }^{3}$, of the epidemic. The methods and the scale of these research efforts vary. Methodologies range from questionnaire surveys to interviewing and text-analysis, to document review, and to the processing of statistical and media data. These studies cover various types of CSOs in terms of their primary objectives, functions, and action domains. In this respect, mostly welfare CSOs (e.g. in the German, Austrian, UK, Indian articles) are examined, but other service CSOs (e.g. educational or cultural in Hungary, or migrants', irregular migrants' services in Turkey), and advocacy (e.g. in the case of the Hungarian article) are also represented. However, these functional categories overlap - most of the CSOs are multi-purpose in terms of their diverse activities. Thus, service functions are typically inseparable from the representation of the interests of target groups (e.g. the poor, the disadvantaged) (Young 2000, 2006), or cultural organizations' objectives from the struggle for the recognition of minorities (Mosley 2010). CSOs, even if they do not directly pursue advocacy, are agents of shaping government policies (Boris and Mosher-Williams 1998; Chinnock and Salamon 2002; Cohen and Arato 1997; Edwards 2009; Habib and Taylor 1999; Van Til 2000) - as the article in this issue by Kövér, Antal and Deák explicates.

No less important are the historical contexts and theoretical frameworks in which the authors interpret the civil sphere of their own societies and governmentcivil sector relations. The Austrian (by Michael Meyer) and German (by Annette Zimmer and Eckhart Priller) research studies conceptualize CSOs, employing the

3 Some studies were completed in September 2020, others extended through October. 
Salamon and Anheier (1998) model, as a corporatist/welfare partnership regime. The South Korean civil society is interpreted by Bok Gyo Jeong and Sung-Ju Kim in the frame of Edwards's three images of civil society: as associational life, as the good society, and as the public sphere (Edwards 2004). The relationship between the government and civil society is classified along two criteria: the level of government involvement and the public policy stage. The first criterion refers to the extent of which civil society contributes to governance in the multi-sectoral partnership, while the second refers to the extent of civil society's involvement in the public policy formulation and policy implementation process. The Hungarian civil society is theorized by Ágnes Kövér, Attila Antal and Izabella Deák partly in the well-known frame of Young's (2000, 2006) complementary-supplementary-adversarial model, and partly in the improved 4C model of Najam (2000) which was modified to fit authoritarian conditions. This theoretical model of the authoritarian state's impact on civil society provides an adaptable frame for understanding the plight of Chinese and Turkish civil society, as explained in the commentary in this issue by Mark Sidel and Ming $\mathrm{Hu}$, and the article by Erhan Dogan and Deniz Genc, respectively.

A group of studies focused primarily on the devastating social impacts of COVID-19. Government-CSO relations were examined in light of government's ability to provide the means for CSOs to carry out their often momentous, sometimes life-saving tasks during the crisis. The accounts of the United Kingdom by Margaret Harris, and of India by Rajesh Tandon both embedded their analysis in different maleficent social processes which emanated during the pandemic or increased and became more visible as its result. The positions of the 10 million "unshielded", so-called "less vulnerable" population in the UK, the unprotected and destitute internal migrants in India, and in the same vein, the irregular migrants in Turkey or the disadvantaged rural population (often Roma) in Hungary, are at the core of these social processes.

\section{The Scale}

There are many ways to structure and theorize civil society-government relations, and to examine the functioning and main characteristics of civil society in this context. Pauly, De Rynck, and Verschuere (2016) examine civil society-government relations from a neo-Gramscian perspective and analyze the transition from government to governance - especially participatory governance. Rules, practices and narratives form the nodal points of CSO-government relations in their analysis. In the field of social theory, Riley and Fernández (2014) challenge the bottom-up versus top-down approach and the context of heteronomous versus autonomous civil society in the totalitarian and authoritarian state regime's frame of reference. 
Infiltration theory (Klein and Lee 2019) draws on the idea that the main feature of civil society is interdependence rather than independence and the boundaries of the actors (government-CSOs-market) are permeable or blurred (Van Til 1988). This theory, which encompasses civil society-government-market relations, distinguishes between forward and backward infiltration among each of the actors. Inside these categories the authors differentiate among policies of influence, policies of substitution and policies of occupation (Klein and Lee 2019). This theory provides a dynamic view of civil society-government-economic actors' interrelations and analyzes the possible permeations effectuated by the

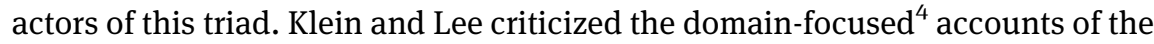
politics of civil society, whose thrust is to preserve the autonomy and distinctiveness of civil society from the intrusion of state or economic actors. Rather, they argue, there are mutual permeations among the sectors and that disparate forms and strategies of infiltrations are almost unavoidable. Moreover, these permutations determine the quality of relations of the actors in the triad. Contrary to Klein and Lee's model, Grønbjerg and Smith (2021) argue that the relationship of civil society-government-market-informal (household) actors varies systematically across the domains, as they explicate the applicability of the domainbased conceptual frame. In Young's $(2000,2006)$ theory, the supplementary and complementary model relates the government and CSOs in a service provision context, while the adversarial model highlights the advocacy or watchdog function of civil society. The theory is well supported by historical evidence and clearly indicates the ways by which the two domains have infiltrated each other's fields. Finally, Najam (2000) whose 4C model was adapted to authoritarian conditions in Hungary in the article within this Special Issue, distinguishes four types of relations between the government and civil society: cooperation, co-optation, complementarity, and confrontation. According to Klein and Lee (2019) most analysis of government-civil society relation limits itself to the of politics of influence and it is therefore unable fully to describe the complex reality of these relations.

Embedded in these theoretical understandings, this introduction examines the research articles of this Special Issue in which authors unfold the dynamics of CSO-government relations in the context of the world pandemic. These accounts sharpen our understanding of the preexisting shape of government-CSO relations. If we wanted to place the countries on a scale which classifies them according to the characteristics of civil society-government relations unfolding during the pandemic, one of the endpoints would be represented by those countries where the

4 Domain-focused approaches examine civil organizations in the contexts of fields or domains where they perform their activities. 
CSO's creative and constructive responses to the social challenges were prevented or blocked by the government. In this setup, CSOs were ignored at best, and restrictions undercut their abilities to contribute to the process of mitigating the pandemic and its consequences. Meanwhile, at the opposite end of this scale, are countries where the government, both central and local, invited civil society partners in the response to COVID-19, orchestrated high-quality and multilevel cross-sectoral cooperation, and provided partners with the necessary (financial) resources. In those cases, CSOs were empowered effectively to participate in a process designed to address the epidemic and its consequences in accordance with principles of participatory democracy.

The quality of CSO-government(state) relations can be gauged along the dimensions of autonomy, partnership, and inward and outward solidarity. According to Salamon and Anheier's (1998) seminal work on “social origins", which highlights the civil sector's embeddedness in broader social, political, and economic realities, underlying eco-political regimes determine the relationship between government and civil society/civil sector. The predominant factors are autonomy (Read 2008), partnership (participation) (Gaventa 2006; Sørvoll and Bengtsson 2019) and solidarity (inward and outward (or political Foley and Edwards 1996). These three factors - discussed by a great many social scientists capture the deep characteristics of civil society, linking it to democracy. Walzer identifies this as the "civil society argument": "Only a democratic state can create a democratic civil society; only a democratic civil society can sustain a democratic state. The civility that makes democratic politics possible can only be learned in the associational networks.” (Walzer 1992, 104)

Autonomy of civil society and its organizations refers to a balance between autonomy from the state and autonomy from the market, as well as emphasizing the role of norms of trust and reciprocity (Della Porta 2020). The autonomy of civil society in particular, depends on its ability to protect itself against both subsystems (state and market) (Cohen and Arato 1997) since it can be jeopardized directly by state/governmental power (Tocqueville 2000) and by the colonizing tendencies of economic forces (Cohen and Arato 1997).

Autonomy and independence are intertwined notions. In countries dominated by authoritarian regimes, CSOs are subjected to direct (legal and/or political), top-down control by an all-embracing state, whereas in more democratic marketbased countries where state-civil society cooperation takes the form of participation and collaboration, resource dependency might jeopardize the autonomy of CSOs. Interestingly, the state only appears as a threat to civil society in the liberal concept; in the communitarian conception the role of the state is central and its impact on civil society (and narrowly on CSOs) is not considered as encroachment (Walzer 1998). Therefore, the communitarian social concept is often utilized as legitimating 
ideology for authoritarian endeavors. This is clearly traceable in the case of the Chinese, Turkish and Hungarian cases' government-CSO relations, where populist autocracies are in power and frequently refer to communitarian ideals.

Partnership refers to collaboration among actors who seek common or complementary ends. Embodied in participatory democracy, participatory governance and decision making, its ideal form is deliberative democracy. Partnership means power sharing over the decision(policy)-making process, which has a double consequence: on the one hand a better public policy emerges that takes into account the needs of communities; on the other hand civilians themselves become interested agents in implementing the jointly developed policies. Pauly, De Rynck, and Verschuere (2016) explore how the relationship between government and civil society has been described in terms of a shift from 'government' to 'governance' and how this shift is, to a great extent, based on underlying theories of modernity. The "partnership argument" became pivotal in the "third way" critique and redesign of welfare states at the end of '90s, drawing on Giddens' assessment of the welfare political endeavor which disempowers civil society. Giddens' (1998) critique of classical social democracy revolved around "the centrality it attributes to the state in social and economic life, and for its distrust of civil society." (Mouffe 2005, 57) As Giddens argues, "to allow for a widening of democracy, it is necessary to reform the state and government to make them act in partnership with civil society." (Mouffe 2005, 58)

Solidarity is embodied in norms of reciprocity and common interests as well as mutual support within and among groups. Inward solidarity refers to a quality of human association, specifically the cohesive social bond that holds the members of an organization together in an association based on some level of conscious or intentional commitment (or "group identification") on the part of members (Rehg 2007). At the same time, inward solidarity encompasses sectoral solidarity, in which organizations' collective goals transcend the interests of individual organizations (Sørvoll and Bengtsson 2019). Good examples are the Hungarian and the South Korean cases where the small and weak CSOs, mostly working in disadvantaged rural areas, were supported by the bigger and stronger ones who launched fundraising campaigns and collected donations to enhance their survival and that of their target groups. Alternatively, outward solidarity denotes the process in which CSOs strive to influence state policies by external activities, such as public debates and using different influence strategies over government policy (Sørvoll and Bengtsson 2019). In this context, civil society is a counterweight of the (unresponsive or authoritarian) state; thus, "citizens pressure authoritarians for change, protect themselves from tyranny, and democratize from below" (Foley and Edwards 1996: 46). In Young's $(2000,2006)$ theory this may be viewed as the adversarial function of civil society; or in the infiltration theory, this would cover the politics of influence 
which focuses on pressuring incumbent policy makers or market actors to respond to the claims of civil societies (Klein and Lee 2019).

Applying these indicators at the end of the scale where CSOs are disempowered, we might place China, commented on here by Sidel and Hu. Though the Party and state-directed responses to COVID-19 allocated a role for civil society groups primarily in helping to provide services and in raising funds - those roles were subservient to state activities and were directed by the state. As Sidel and $\mathrm{Hu}$ explain, the COVID-era did not result in the advent of autonomy for Chinese civil society. COVID-specific CSO-government relations were based on preexisting, restrictive policies and statutes that have limited the role and autonomy of civil society organizations in China.

The application of certain theories blurs the concept of autonomy regarding Chinese civil society-government relations, where its absence is interpreted in permissive and non-negative terms. This tendency can be seen in the application of agency theory which emphasizes that there are "complex patterns of interaction between the state and society" in the Chinese context, and often refers to concepts such as "interdependence", "embeddedness" and even "dependent autonomy” and “contingent symbiosis" (Stigum Gleiss and Sæther 2017). In a similar vein, another theoretical framework, which can be traced back to Durkheim's notion of organic solidarity, emphasizes complementarianism and interdependence as pivotal ingredients of civil society-state relations (Gao 2012). However, these theories seem to "dress the naked emperor", embellishing existing authoritarian relations and lack of autonomy and explaining them in positive terms. They deny the suppression of the adversarial function of civil society, which concomitantly destroys the criterion of outward solidarity. Summarizing the lessons of COVID-19 on civil societygovernment relations, Sidel and $\mathrm{Hu}$ assert that in such a strong, authoritarian state like China, where the state puts strong, restrictive policies in place toward civil society as the "normal course of business", these frameworks are not altered when a crisis such as COVID-19 hits. As they explain, the Chinese structure of authoritarian arrangements toward the charitable sector can adapt to even a major shock to the system such as COVID-19. The Chinese commentary points out the primacy and exclusive defining role of the state in government-CSO relations, which certainly challenges the view that nonprofits are necessarily a liberalizing or democratizing factor in autocratic regimes.

Next to the autonomy scale, is Turkey, analyzed by Dogan and Genc, where a significant part of civil society is characterized by religious and pre-modern aspirations. However, new fault lines are already visible compared to the earlier monolithic picture, especially after the last municipal elections, when opposition representatives came to power in Istanbul and several other large cities. In the COVID-era, this dissent of civility was well demonstrated, offering an alternative to 
the central government's claims for exclusivity. The fundraising actions of local (opposition) governments and civilians were declared illegal by the central government, yet the viability of civil society was demonstrated by the witty and creative actions that have circumvented the central will and have effectively helped those in need in local constituencies. CSOs worked jointly with local and district government machinery to identify beneficiaries in the community, and to link them to services or enroll them in relevant schemes. A whole host of ingenious and shrewd solutions have been developed by local civil actors, such as the campaign entitled "paying a neighbor's bill” (Askıda Fatura). In this campaign, a digital payment portal is provided for those citizens who want to pay the water and gas bills of fellow burghers who had lost their livelihoods because of the pandemic. This vivid example points out that CSO-government relations are clearly defined by the characteristics of authoritarian systems, where the government is an active and intrusive shaper of civil society producing policies which exclusively support those organizations that comply with the system. At the same time, the outward solidarity, or the adversarial function of civil society is not tolerated, not even in the case of the so-called pro-government CSOs. Dogan and Genc interviewed one of the pro-government organizations' members, who asserted that "whenever they criticized government or state institutions, they felt they were being ostracized by the relevant state authorities and their networks." However, the aforementioned account also exemplifies the ingenuity of civil society and the form of resistance that manifests itself in inward solidarity. This phenomenon is found in the Hungarian article here as well.

During the pandemic, pro-government NGOs sought to collaborate with the authorities, but their work, just like the work of other CSOs, was largely ignored by the government. The criteria of autonomy, partnership and outward solidarity proved insufficient. In times of crisis as those of the pandemic, autocratic governments seek to take advantage of emergencies to further strengthen their positions vis-a-vis civil society by further advancing authoritarian forms and structures.

In both Turkey and China earlier crises, deriving from natural or social disasters, led to some weakening of governmental control. The Marmara earthquake in 1999. the Syrian refugee crisis after 2015 in Turkey, and the Yinchuan earthquake in Sichuan in 2008 each evoked a recovery and strengthening of civic activism, voluntarism and a more active and independent civil society. However, these efforts were thwarted after the disaster and governments enacted increasingly restrictive and/or coopting policies against CSOs that hampered their autonomous aspirations (Sunata and Tosun 2018; Xu 2017). In Turkey, civic activism was diverted into NGOs endowed with religious ideologies and pre-modern characteristics that do not strengthen Turkish civil society or democratization but promote the reproduction of the reigning system (Sunata and Tosun 2018). In China rigid restriction policies were 
enacted toward domestic as well as overseas NGOs in order to impede any cooperation between them.

These aforesaid processes are found in the study of Hungary, next over on our scale. This study applies the Najam 4C strategy in a modified form, adjusted to authoritarian societies. Ultimately, the same processes can be observed for all authoritarian regimes in relation to civil society-government relations. It is a futile question as to whether the causes of these processes are rooted in the qualities of a strong government or state, or a weak, polarized civil society. These qualities mutually reinforce each other, and as a result CSOs are prevented from acting as agents of democracy.

On our autonomy scale, a country like Hungary may be placed where an asymmetry of power allows the governmental actor to seek its desired hegemony including consensus - by applying increasing levels of coercion, as the authors, Kövér, Antal and Deák report. These authors conceptualize government-civil society relations according to a "4C strategy" - Cooptation, Coercion, Crowding out, and Creation (the creation of a new, loyal civil society). Based on pre-existing CSOgovernment relations, the Hungarian government showed no intention to cooperate with the civil sector and the wider civil society, which might have served as an effective force in averting the consequences of the pandemic, alleviating the difficulties faced by people, and managing the conflicts that arise. The relationship between government and civil society in the epidemic has also been unilaterally defined by the stronger party. The government of "National Cooperation" ignored the opportunity to organize cross-sectoral cooperation and relied solely on its own central resources as being the "sole actor on the stage". The critical literature (e.g. Alvez and de Costa 2020; Simo and Bias 2007) concurs with the conclusions of the studies presented in this volume, that cross-sectoral cooperation magnifies government efforts and increases public confidence as well as social cohesion. Central government neglect, and in certain cases, hostile attitudes, have had surprisingly little impact on Hungarian CSOs, which in large part continued doing their job and taking responsibility for those who are in need and seeking support. Civil groups and CSOs organized unprecedented fundraising, used their own resources to support the disadvantaged, provided extra services, set up meal banks where needed, distributed digital equipment among children, and assisted the elderly and those living with disabilities. All these efforts were neither recognized nor compensated by the government. The multifaceted adverse governmental practices against CSOs proves that the Hungarian regime does not trust its civil society. Rather, it seeks to create a hegemony that requires consensus, by establishing pseudo-civilian organizations, and by continuous and extensive instrumentalizing of Hungarian minority organizations outside the border. However, this is only partially sufficient for legitimacy based on a symbolic or communitycultural definition (Daloz 2009; Farkas 2015). The system's efforts to control civil 
activism tend to fail and members of society, at least from time to time, show that they understand the importance of independent CSOs and their social responsibilities.

Continuing along our scale, we move towards countries that might be less authoritarian but still disregard civil society and do not very often engage its forces in joint efforts with government. Israel offers a good example for this. As Schmid points out in his commentary, the government's policies can be characterized by a lack of support for the work of CSOs, often threatening their very survival. The Israeli government's ambivalence towards civil society consists of various well-known prejudices. One of them is that "CSOs which operate on the basis of the values of democracy, equality, freedom of expression, and the right to demonstrate and advocate for disadvantaged and excluded populations, undermine the stability of the government and the resilience of the country", Schmid asserts. This point of view perceives CSOs as subverting forces which undermine governmental actions, constituting a "deep state" - as Schmid calls it -, which is known in a different context as "shadow government" or "shadow state” (Haque 2002; Kamat 2004; Sutton and Arnove 2004). This expression often appears in developmental studies.

To avoid conflating the standpoints of developmental studies with the issues of the "deep state" referred to by Schmid, we should briefly examine these approaches and their evolution. Developmental studies explore the issue of shadow government from the perspective of neoliberal globalism versus national sovereignty, asserting that the presence of international NGOs sometimes facilitates the neo-colonial tendencies of neoliberal capitalism. Here, serious criticism was leveled against international NGOs (Jad 2004; Kamat 2003, 2004; Manji and O’Coill 2002; Roy 2014) which were echoed and instrumentalized by national governments leaning toward authoritarianism, resulting in a shrinking space for civil society. The aforementioned Chinese experience is an extreme example. In this distrustful discourse, national governments infiltrate the civil sector, and obstruct civil society's ability to express criticism, while civil society seeks to hold politicians and government accountable. "Usually, discord and mistrust emerge from the actions of civil society which produce evidence to hold the government and political machinery and actors accountable" - as Rajesh Tandon notes in his article here about Indian civil society. All in all, the more authoritarian a political regime, the more it tends to perceive "civil society' as posing a threat to the reigning political order. At the same time, these perceptions question the adversarial function and impede the outward solidarity of civil society and contextualize it with a conflict paradigm (Salamon, Sokolwski and Anheier 2000), according to which the relationship between the nonprofit sector and the state is fundamentally competitive. In contrast, for South Korea, Jeong and Kim reframe the deep state phenomenon along the lines of collaborative governance, based on Kettl (2000). 
Another underlying prejudice against CSOs is that they are perceived to be ineffective and inefficient, especially in comparison with for-profit organizations. Schmid clearly depicts the contradicting expectations directed towards CSOs as setting a dangerous trap for them. He explains that the Israeli government prefers for-profits to provide welfare services rather than CSOs. Favoring organizations that "only" strive to gain profit makes them more transparent and therefore less threatening from the government's perspective, and at the same time does not favor the commercialization of non-profits, thereby sustaining a suspicion that nonprofit organizations seek to make profit despite their declared motivation.

CSO-government relations were characterized by these antecedents when the pandemic hit in Israel. The lack of trust and the missing paths and practices of cooperation ultimately made it impossible for civil society to play an active and effective role in fighting the virus and mitigating its consequences. Accordingly, the government did not aid CSOs in the crisis, "rather governmental agencies piled up bureaucratic obstacles" and let organizations fade and collapse, even die, intensely highlighting the government's position toward civil society.

The next country on the scale might be India, where, arguably, constructive cooperation has characterized CSO-government relations. As Rajesh Tandon summarizes in his study: "India's civil society acted both independently and in close cooperation with national, provincial and local governments" and responded efficiently to the distress caused by the pandemic and the lockdown. CSO-governmental relations were harmonious, with contributions of civil society encouraged by the government. However, as the pandemic crisis unfolded, tensions grew, overturning the harmony of cooperation and creating mistrust. Particularly two unilateral governmental actions contributed to undermining trust. The first was limiting public consultation on important social issues which led to the passing of legislation and constitutional amendments that have worked to the detriment of environmental protection, labor and farmers. The second was establishment of a fund where sums earmarked for other societal purposes (like social welfare) were channeled into, and into which donations to CSOs from national or international donors were diverted. This process undermined the service and survival potential of grassroots social welfare organizations, asserts Tandon. "NGO-Government Relations: A Source of Life or Kiss of Death?” - this well-fitting title of Tandon's paper, illuminates the dynamics of cooperation and contestation between state and civil society. Although the government cooperates with CSOs on a local level, a growing intolerance has emerged toward civil society - questioning or critiquing policies, programs and procedures that do not help the poor and the excluded. All this casts a dark shadow over CSO-government collaboration in India.

Further along the scale are three welfare societies where most of the criteria we set at the outset have slowly been met: in Germany, Austria, and the United 
Kingdom, autonomy, participation and solidarity unfolded in rather complete forms.

Zimmer and Priller, examined Germany in the context of corporatist federalism. A high level of decentralization, multi-level governance, and a long tradition of voluntarism are all characteristics of this scheme. The majority of CSOs operate in the field of social welfare, and the system, as in the case of Austria, follows the corporatist model of the Salamon and Anheier (1998) classification, which locates these countries as high in government expenses and high in the prominence of nonprofit organizations. Corporatism or neo-corporatism ${ }^{5}$ represents the incorporation of societal actors into the policy process on each level of governance, typically by means of non-parliamentary negotiations and deliberation, and close cooperation between the state, large associations, and other social actors (Zimmer 1999). This system demonstrates successful participatory governance and policy making, on the levels of policy development and policy implementation. However, as the authors explain, in recent decades, the neo-corporatist tradition of the country has diminished and is no longer strongly in place.

Although the traditionally existing, balanced nonprofit sector-government cooperation worked functionally and proved efficient during the pandemic and the benefits of the corporatist system - including the elements of autonomy and solidarity - unfolded, the authors report several areas of concern. They find no notable difference between for-profit and nonprofit service providers in the social domain and observe that nonprofits are treated on equal footing with for-profits. Consequently, most nonprofits operating in this domain have become more business-like in recent years. This government strategy was particularly intense during the pandemic, as both federal and regional governments treated nonprofits as if they were businesses and market players. The authors are concerned that the specific characteristics of nonprofits have not been recognized in government rescue programs, neither at the federal nor regional levels, and that they have been treated as a proxy of commercial enterprises. This process threatens to further commercialize or hybridize nonprofits, affecting organizational design and practice. Further, it takes a big step towards social service commodification, undermining norms and values inherent to this sector which have long stood as justification for the primary engagement of nonprofits in these fields

\footnotetext{
5 Neo-corporatism developed from the previous corporatist tendencies of German and other European societies. Previous authoritarian regimes have sought to incorporate social groups into state-controlled frameworks. The "neo" label in front of the noun serves to indicate a more moderate form of the interest group structure in which highly stratified interests (e.g. a diverse group and local interests transmitted by NGOs) and a strong democratic state exercise new patterns of interest intermediation (Dalton 2007).
} 
(Anheier and Krlev 2014). The authors report a shift in membership-based organizations toward contract-like relationships in which charges must be paid for services received.

Regarding the partnership criterion, the authors report that the Federal Government handled matters in a top-down manner and did not give civil society a voice. Regional governments which developed effective programs and invested significant resources into recovery projects behaved similarly. Programs were not developed in partnership, and, as the authors note, in some cases, local politicians forged their own political capital using the pandemic. One consequence of the lack of feedback and participatory planning was that bureaucratic measures were not relaxed, which made accessing (or coping with) programs more difficult, particularly for smaller organizations. However, the authors highlighted that even though the policies of regional governments were not coordinated and followed disparate patterns, all of them were planned and carried out in a party-politics-free manner. Another positive development was that in some provinces, local governments saw an opportunity in the pandemic to further strengthen cooperation with a wide variety of organizations.

Zimmer and Priller's paper also draws attention to processes that are expected to have a significant impact on German civil society even after the crisis. They highlight the professionalization of non-profits and the increasing exclusion of volunteers from formalized organizations, but at the same time, increases in more spontaneous, less formalized, fundamentally neighborhood-based volunteering and civic engagement. The latter manifested as part of an explosion of solidarity during the epidemic, when spontaneous volunteering rocketed far beyond demand and placement opportunities. The authors also expressed concern about the accelerating polarization of German civil society along pro-democratic versus nationalist lines. During the COVID-era, the concept of "charismatic leadership" also became popular and will likely influence the country's political culture in the future. In light of the spread of populism and polarization in Europe, these phenomena are increasingly worrisome.

Austria, like Germany, can be characterized as a federal corporate system. Its corporative schemes are particularly dominant in the field of social services and healthcare, where $80 \%$ of organizational revenue comes from government sources. According to Meyer's study here, CSOs in Austria have been severely hit by the pandemic and the resulting closures. In the early stages of the pandemic the federal government began negotiations on fixed-cost subsidies for NGOs, in a democratic process involving CSO representatives. This reflected an exceptional perspective in which social service providing CSOs are seen as stabilizers of the economy. Austria is unique among our nine countries in that it reports a positive impact of the epidemic on government-nonprofit sector relations: With the creation of its nonprofit fund, 
the nonprofit sector has been legally recognized for the very first time. This legislation was passed at the height of the epidemic so the government could allocate the enormous resources ${ }^{6}$ made available for the sector, since criteria by which CSOs are defined were previously missing. This made CSO-government relations more transparent and stable. Meyer's paper presents remarkable empirical research, in which a focus group discussion reveals strengths and weaknesses of cooperation between different levels of government and NGOs working in social and health services. Perhaps its most important findings are: First, the more trust that had already been built up in previous cooperation, the better the collaboration worked during the pandemic. We have seen, for example, in Schmid's commentary on the situation in Israel, how a lack of trust and prejudice reinforce each other as a vicious cycle, and how society and political action lose the potentials that lie in their own NGOs. Second, the rapid introduction and application of new technologies, has sped up the coordination procedures between the government and CSOs and made them more efficient. Finally, the lack of standards or their variations from province to province caused confusion among NGOs and made it difficult for them to cooperate. The Meyer study does not raise concerns about the marketization and hybridization of CSOs. Moreover, it recommends that the government encourage NGO entrepreneurship to enhance autonomous and flexible responses to crises. The study does, however, raise concerns about state paternalism intensifying as a result of the pandemic, particularly with respect to the smaller CSOs.

A kind of inversion of civil society-government relations can be observed towards the end of the scale. Contrary to the authoritarian extreme where the governments excluded - or at best, ignored - CSOs from remedying the consequences of the pandemic, in the United Kingdom the state left the resolution of problems mostly, or in the case of certain social groups, exclusively to CSOs. Here, civil society found itself overwhelmed by the magnitude of tasks expected of it and assigned to it.

The U.K. is identified as a mixture of the liberal and the corporatist regimes by Salamon and his coauthors (2000) and as a marketized welfare state by Harris (2018). Harris's paper in this issue confirms that previous patterns of CSO-government cooperation have persisted in the COVID situation. The study highlights that the boundaries between the government and the civil sector are blurred, with the state shifting responsibility for the social sphere to the civil sector, often showcasing as though these were governmental services. Harris has previously described this as the government's encroachment to the field of civil society (2018), which also

\footnotetext{
6 As Meyer noted, „the overall payout per CSO was capped at the loss of revenues in 2020 in comparison to that of 2019, and at a total of 800,000 Euro per CSO. From a comparative perspective, this nonprofit fund is more generous than the fund for business enterprises."
} 
manifests itself as an attempt to limit the functions of advocacy and lobbying while strongly encouraging civilians to provide welfare - social services, especially those that the state considers important (Harris 2018). Limited state responsibility has also characterized the pandemic, although the government did take responsibility for the most vulnerable 1.5 million people. A second group of 10 million people, defined as less vulnerable but still socially isolated, have been left to the charity sector.

However, Harris mentions some positive changes during the period of COVID-19. For example, beyond the strongest, formalized charities local NGOs were given the opportunity to get involved in local crisis management; regulations have become flexible, which aided a faster and more flexible response, and assisted the involvement of more volunteers; significant financial support was provided by the government for charity organizations - though this was deemed insufficient. The huge number of volunteers were provided pivotal experience who in the first days of the pandemic could hardly be accommodated by the organizations. The importance of the role of local society and neighborhood networks, which often provided the first responses to local crises, has been demonstrated as well.

One might be hesitant to judge the last three countries by the criteria we have examined. The German and U.K. experiences show that the shift towards marketization, as a result of contract competition, professionalization (understood as new public management rules), and the fact that nonprofits are treated by the governments as if they were businesses or market players, have put CSOs at risk. In addition, in the case of Austria, the fear of government paternalism has arisen. These concerns suggest that the autonomy of the civil sector might be threatened by the market and by governmental paternalism. Further concerns could emerge in connection with participation and participatory decision-making, especially in case of Germany.

In South Korea, the study by Jeong and Kim in this issue shows that CSOgovernment relations most comprehensively meet the requirements of autonomy, partnership and both forms of solidarity. As in the other countries, the whole society and civil sector have been adversely affected by the epidemic. NGOs have suffered huge losses, with $70 \%$ of non-profits having to terminate or reduce their programs, losing more than half of their revenue. Yet beleaguered South Korean organizations responded to the new conditions in a flexible manner. South Korea is one of the very few countries where there have been no closures, no curfews, and the economy, education and all other areas of life continued steadily during the pandemic. As well, South Korea is one of the most successful countries in controlling the spread of the epidemic, with one of the lowest death ratios and the highest number of tests done, mostly free of charge. The 3Ts (Test, Treatment, Tracking) strategy added another T: the Teamwork factor, which was the key to success in the COVID-19 response. From the outset, 
government strategy involved civil society, and many levels of collaboration and partnership in the design and implementation of decisions. Jeong and Kim found that Edwards' (2004) three images of civil society - as associational life, civility, and the public sphere -, were all successfully manifested during the response to COVID-19 in South Korea. Civil society was involved in more than just the defense against the pandemic, but it also prepared for the future even in the most difficult moments and exemplified outward solidarity. An unprecedented coalition of 530 NGOs formed a civil coalition to call for structural change on the public policy level by creating the Civil Society Counter-measure Committee to the COVID-19 Societal and Economic Crisis. The coalition's purpose is protecting the vulnerable part of the population by expanding the societal safety net and public health support, and by helping to make the economy more sustainable.

Community-based fundraisers were highly successful in raising a significant sum, which helped the disadvantaged population and those stuck in quarantine. As the authors aptly explained, in the fight against the epidemic, the government was not behaving like a "Single-actor Play on Stage." Instead the co-directors of government, private actors, citizens, and civil society were all involved. The South Korean government was thus able to make maximum use of the strength and resources of civil society and the civil sector. Meanwhile, the government enabled and empowered them - both with financial resources and partnership to participate in the joint struggle in the most efficient way possible. South Korea offers commendable examples of inward and outward solidarity, where larger NGOs raised funds to help smaller, distressed organizations, and where significant cooperation at a national level has strengthened civil society advocacy.

The apparent success story in South Korea must be viewed with caution, given the unavoidable limitations of Jeong and Kim's study. The data used in the study were exclusively derived from government's or individual nonprofits' websites and their official announcements or press releases. The authors have acknowledged that these sources may be biased since the government and CSOs may showcase successful models and programs, and not report publicly on unsuccessful or failed attempts. Moreover, the data include only the official events appearing on these websites, their components and participants, their officially announced objectives; however, the study did not examine the actual interaction between the parties or their impact on the public policy process.

\section{Closing Remarks}

This essay examined CSO-government relations in the time of COVID-19, introducing the articles and commentaries presented in this special issue of the 
Nonprofit Policy Forum. The analysis was developed to follow the concepts of autonomy, partnership, and solidarity, which are fundamental principles of the civil sector. In line with our expectations, the articles found that government-NGO relations did not show much deviation from pre-existing qualities and practices. This is consistent with Salamon and Anheier's (1998) influential concept of "social origins" which spotlights the civil sector's embeddedness in broader social, political, and economic realities. The crucial cleavage is between countries that are predominantly authoritarian and those with a predominantly democratic political system, which is also not surprising. The predominantly authoritarian political regimes were either at best unable to cooperate with their own civil societies, or CSOs' activities were highly restricted, fully controlled and subjugated to state direction which deprived them of autonomy and participation. Sometimes governmental leaders even sought to prevent civilian solidarity actions or threatened CSOs and their members with criminal penalties. In these countries, governments behaved as "single actors" and failed to channel the potentials of civil society to help overcome the pandemic and alleviate its consequences.

The studies of this volume have shown that in an authoritarian polarized society, everything is over-politicized. Even the simplest issue has political significance because its critical edges may violate the hegemony of those in power. Therefore, in politically polarized societies, the plight of CSOs is very difficult. The article on Turkey reported that CSO representative interviewees viewed the high level of political polarization as a principal obstacle for their operations. As authors Dogan and Genc stated, they had to act very cautiously, and they tried to stay out of politics. Otherwise they were suppressed by the central government, their applications were delayed, their fundraising campaigns were declared illegal, and their usage of local government facilities was restricted, etc. Hungarian interviewees gave similar accounts and the empirical research indicated the risky nature of criticizing or publicly disagreeing with the governmental policies. It remains unclear whether highly polarized society leads to populist authoritarianism or that populist authoritarian policies deepen the cleavages in societies.

Most studies in this volume have, in some way, spoken on how the public space in which civilians can express their opinions without retaliation is narrowing. The studies from Israel, India, Austria, Hungary, and Turkey draw particular attention to this. Of course, government reactions are diverse, ranging from disapproval to deprivation of resources to deprivation of personal freedom.

However, the uplifting manifestations of solidarity and volunteering have shown that even in countries where public space for participation and outward solidarity is restricted, civil organizations have the courage and ingenuity to occupy 
"metaspace"7, "a fluid form of public space. . .[with] different definitions and different ways of participating in it”. Metaspace has the ability to hold simultaneously contradictory approaches and a "container of knowledge-management processes, [for] the dynamic chaos in which we live" (Bunschoten 2003, 59). This is a highly political space, but not in the sense of party or state power-politics, though this space contains enormous amounts of power. This space is impermeable by those in authoritarian state-power because this is the space of resistance. The resistance is always present where there is power. As Foucault pointed out, power may form disciplined individuals, who are rational, productive subjects, yet that is in no way an expression of human nature. Furthermore, there is always at least some resistance to the imposition of any particular form of subjectivity, and thus resistance is concomitant with the process of subjectification. "As soon as there is a power relation, there is the possibility of resistance.” (Foucault 1978, 95)

In countries with traditionally democratic regimes, although civil society government relations can be endangered from many directions, the autonomy of civil society and NGOs is fundamentally guaranteed, and so is their place in participatory governance. Their efforts are recognized and they play an important role in society and in the formulation and implementation of its social policy, as well as in the improvement and daily practice of democratic values. The result is joint efforts to protect against the virus and to mitigate it social consequences. In these countries, albeit with some nuances, the government has supported CSOs, helping them to survive their distress and remain active, constructive participants.

However, experiences during Covid-19 also confirm that NGOs in developed democracies are faced with increasing retrenchment of the welfare state and neoliberal marketization. The shift towards marketization emerges from resource dependency, government-imposed conditions (Zimmer and Priller study in this issue), competition for contracts, compliance with market donors (Eikenberry and Kluver 2004), and increasing entrerpreneurialism (Sandberg, Elliott, and Petchel 2020) and has a serious impact on the civil sector. A few of the adverse effects of this are analyzed by Eikenberry and Kluver (2004), Heying (1999) and others when they ask how nonprofit organizations will provide an alternative to the market if they behave like market actors. In the COVID-19 situation, government-nonprofits relations were determined by the former's strategy, which dealt with them as equivalents, as Zimmer and Priller report. Thus, the special characteristics of CSOs were not acknowledged, which would have justified a different treatment for them. If the government treats for-profit and non-profit NGOs the same, this will

7 The metaspace theory, a concept of Bunschoten defines it as: It is the site of the search for knowledge; it is the container of knowledge-management processes, but it is also a vehicle for the search for meaning in the dynamic chaos in which we live. 
necessarily mean a further shift towards marketization and hybridization, which, according to Sanberg and her colleagues, in the context of nonprofits, is a "situated process" in that the meta-logic of neoliberalism - with its discourses of entrepreneurialism, prudentialism, and the technologies of performance and citizenship - interacts with and adapts to localized discourses to produce variation and thus unique entities that are still recognizable as marketized (Sandberg, Elliott, and Petchel 2020, 506).

Several studies in this issue (e.g. Harris, Zimmer and Priller) describe how civil society is split into formalized, professionalized, marketized large NGOs on the one hand, where voluntarism no longer has much, if any, room, and on the other hand, into grassroots civil organizations, volunteer groups and patterns of neighborhood networks. This divide, according to the authors, will deepen further during the post-COVID period. However, the crisis has made it clear that grassroots, local communities are more flexible and more responsive in case of an emergency.

Surprisingly, in some cases, the epidemic has had a positive impact on government-CSO relations. For example, because the situation following the pandemic spotlighted legal loopholes requiring clarification in Austria, it led to the formal recognition of the non-profit sector as such. The beneficial consequences of this will define the future relations of the actors. Similarly, the United Kingdom research finds that the government sees civil society as a serious partner in the aftermath of the pandemic. The question of whether the changes that have emerged during the epidemic will truly take hold, leading to a real structural revaluation of governmentCSO relations, remains. Or will the aftermath take the form of a carnival, where everyone leaves their comfort zone for a while, but ultimately returns to their routines when the fantasy ends (Baumann 2013).

I would like to conclude with some examples that show how creatively, and innovatively civil society has been able to respond to the crisis. We witnessed the proliferation of innovative forms of fundraising, the rapid spread and extensive innovative use of information technology, the explosion of volunteering, an unprecedented level of activity of the formalized civil society, and the revival and flourishing of local and neighborhood networks. We conceived new words and phrases that have become part of our everyday lives. We invented phrases like: 'digitally volunteering', 'online guided tours', 'quarantine concerts', 'food ingredient donation', 'paying a neighbor's bill', 'sharing volunteers', 'drivethrough agricultural products marketplace', 'hot meal for everyone' and finally the 'Grassroots Support for National Health System Staff'. Surely there are more new terms to add to the list, but these and others found in the articles compiled here, illustrate the strength and ingenuity of CSOs and civil society, and their ability to cope with incredible challenges, like the pandemic, COVID-19. 
Acknowledgements: I would like to express my gratitude and appreciation to Jon Van Til, my colleague and husband, for his tenacious support and assistance during the editing of this Special Issue.

\section{References}

Alves, M. A., and M. M. da Costa. 2020. "The Collaboration between Governments and Civil Society Organizations in Response to Emergency Situations." Brazilian Journal of Public Administration 54 (4): 923-35.

Anheier, H. K., and G. Krlev. 2014. "Welfare Regimes, Policy Reforms, and Hybridity." American Behavioral Scientist 58 (11): 1395-411.

Bauman, Z. 2013. Solidarity: A Word in Search of Flesh. https://www.eurozine.com/solidarity-aword-in-search-of-flesh/ (accessed August 20, 2020).

Boris, E., and R. Mosher-Williams. 1998. "Nonprofit Advocacy Organizations: Assessing the Definitions, Classifications, and Data." Nonprofit and Voluntary Sector Quarterly 27 (4): 488-506.

Bunschoten, R. 2003. “Stirring Still: The City Soul and its Metaspaces." Perspecta 34: 56-65.

Chinnock, K. L., and L. M. Salamon. 2002. "Determinants of Nonprofit Impact: A Preliminary Analysis." In Paper presented at the panel session on "Nonprofit Impacts: Evidence from Around the Globe," Fifth International ISTR Conference. Cape Town, South Africa. https:// www.researchgate.net/profile/Lester_Salamon/publication/242075314_Determinants_of_ Nonprofit_Impact_A_Preliminary_Analysis/links/550214040cf231de076da258/

Determinants-of-Nonprofit-Impact-A-Preliminary-Analysis.pdf (accessed August 12, 2020).

Cohen, J. L., and A. Arato. 1997. Civil Society and Political Theory. Cambridge, MA: MIT Press.

Daloz, J. P. 2009. “How Political Representatives Earn Legitimacy: A Symbolic Approach.” International Social Science Journal 60: 285-96.

Dalton, R. J. 2007. A German Political and Economic System. http://www.socsci.uci.edu/ rdalton/ germany/ch7/chap7.htm (accessed July 27, 2020).

Della Porta, D. 2020. "Building Bridges: Social Movements and Civil Society in Times of Crisis." Voluntas 31: 938-48.

Edwards, M. 2004. Civil Society. Polity Press in association with Blackwell Publishing Ltd.

Edwards, M. 2009. Civil Society. Cambridge: Polity.

Eikenberry, A. M., and J. D. Kluver. 2004. "The Marketization of the Nonprofit Sector: Civil Society at Risk?" Public Administration Review 64 (2): 132-40.

Farkas, Z. 2015. “A Hatalom Elfogadottsága És Legitimitása.” Szellem és Tudomány 6 (1-2): 209-35.

Foley, M. W., and B. Edwards. 1996. "The Paradox of Civil Society." Journal of Democracy 7 (3): 38-52.

Foucault, M. 1978. The History of Sexuality, Vol. 1. New York: Random House Inc.

Gaventa, J. 2006. Triumph, Deficit or Contestation? Deepening the 'Deepening Democracy' Debate. IDS Working Paper. Institute of Development Studies at the University of Sussex Brighton.

Gao, B. 2012. "Towards a Civil Society Based on Organic Solidarity: The Significance of Interorganizational Cooperation for Chinese Society." The China Nonprofit Review 4 (1): 87-110.

Giddens, A. 1998. The Third Way. Cambridge: The Renewal of Social Democracy. 
Grønbjerg, K. A., and S. R. Smith. 2021. The Changing Dynamic of Government-Nonprofit Relationships. Cambridge: Cambridge University Press.

Habib, A., and R. Taylor. 1999. "South Africa: Anti-apartheid NGOs in Transition." Voluntas 10 (1): 73-82.

Haque, S. M. 2002. "The Changing Balance of Power between the Government and NGOs in Bangladesh." International Political Science Review 23 (4): 411-35.

Harris, M. 2018. "UK Civil Society: Changes and Challenges in the Age of New Public Governance and the Marketized Welfare State." Nonprofit Policy Forum 8 (4): 351-68.

Heying, C. 1999. "Autonomy vs. Solidarity: Liberal, Totalitarian and Communitarian Traditions." Administrative Theory \& Praxis 21 (1): 39-50.

Jad, I. 2004. "The NGO-Isation of Arab Women's Movements." Institute of Development Studies Bulletin 35 (4): 34.

Kamat, S. 2003. “NGOs and the New Democracy." Harvard International Review 25 (1): 65.

Kamat, S. 2004. "The Privatization of Public Interest: Theorizing NGO Discourse in a Neoliberal Era." Review of International Political Economy 11 (1): 155-76.

Kettl, D. F. 2000. "The Transformation of Governance: Globalization, Devolution, and the Role of Government.” Public Administration Review 60 (6): 488-97.

Klein, S., and C.-S. Lee. 2019. "Towards a Dynamic Theory of Civil Society: The Politics of Forward and Backward Infiltration." Sociological Theory 37 (1): 62-88.

Manji, F., and C. O'Coill. 2002. "The Missionary Position: NGOs and Development in Africa." International Affairs (Royal Institute of International Affairs 1944-) 78 (3) 567-83.

Mosley, J. E. 2010. "Understanding the Policy Advocacy Involvement of Human Service Nonprofits." Social Service Review 84 (1): 57-76.

Mouffe, C. 2005. On the Political. New York, NY: Routledge.

Najam, A. 2000. "The Four-C's of Third Sector-Government Relations. Cooperation, Confrontation, Complementarity, and Co-optation." Nonprofit Management and Leadership 10 (4): 375-95.

Pauly, R., F. De Rynck, and B. Verschuere. 2016. The Relationship between Government and Civil Society. A Neo-Gramscian Framework for Analysis. https://biblio.ugent.be/publication/ 8065871 (accessed November 12, 2020).

Read, B. L. 2008. "Assessing Variation in Civil Society Organizations.” Comparative Political Studies 41 (9): 1240-65.

Rehg, W. 2007. "Solidarity and the Common Good: An Analytic Framework." Journal of Social Philosophy 38 (1): 7-21.

Riley, D., and J. J. Fernández. 2014. "Beyond Strong and Weak: Rethinking Postdictatorship Civil Societies." American Journal of Sociology 120 (2): 432-503.

Roy, A. 2014. The NGO-Ization of Resistance. http://massalijn.nl/new/the-ngo-ization-ofresistance/ (accessed December 10, 2019).

Salamon, L. M., and H. K. Anheier. 1998. "Social Origins of Civil Society: Explaining the Nonprofit Sector Cross-Nationally." Voluntas 9 (3): 213-48.

Salamon, L. M., W. S. Sokolowski, and H. K. Anheier. 2000. Social Origins of Civil Society: An Overview. Working Papers of the Johns Hopkins Comparative Nonprofit Sector Project no. 38. Baltimore: The Johns Hopkins Center for Civil Society Studies.

Sandberg, B., E. Elliott, and S. Petchel. 2020. "Investigating the Marketization of the Nonprofit Sector: A Comparative Case Study of Two Nonprofit Organizations." Voluntas 31: 494-510.

Simo, G., and A. L. Bies. 2007. "Th e Role of Nonprofits in Disaster Response: An Expanded Model of Cross-Sector Collaboration.” Public Administration Review 67 (1): 125-42. 
Sørvoll, J., and B. Bengtsson. 2019. Autonomy, Democracy and Solidarity. The Defining Principles of Collaborative Civil Society Housing and Some Mechanisms that May Challenge Them. Urban Research \& Practice. https://www.researchgate.net/publication/330855416_ Autonomy_democracy_and_solidarity_The_defining_principles_of_collaborative_civil_ society_housing_and_some_mechanisms_that_may_challenge_them (accessed October 26, 2020).

Stigum Gleiss, M., and E. Sæther. 2017. Approaches to Civil Society in Authoritarian States: The Case of China. https://www.duo.uio.no/bitstream/handle/10852/61225/ Revised+manuscript.pdf? sequence $=1$ (accessed March 15, 2020).

Sunata, U., and S. Tosun. 2018. "Assessing the Civil Society's Role in Refugee Integration in Turkey: NGO-R as a New Typology." Journal of Refugee Studies 32 (4): 683-703.

Sutton, M., and R. F. Arnove. 2004. Civil Society or Shadow State? State/NGO Relations in Education. Charlotte, NC: Information Age Publishing.

Tocqueville, A. 2000. Democracy in America. Perennial Classics, Harper Perennial Modern Classics.

Van Til, J. 1988. Mapping the Third Sector. New York: The Foundation Center.

Van Til, J. 2000. Growing Civil Society from Nonprofit Sector to Third Space. Indianapolis, Indiana: Indiana University Press.

Walzer, M. 1992. “The Civil Society Argument.” In Dimensions of Radical Democracy: Pluralism, Citizenship, edited by C.Mouffe, 89-107. Community London: Verso.

Walzer, M. 1998. "The Concept of Civil Society." In Toward a Global Civil Society, edited by M. Walzer, 7-28. New York: Berghahn Books.

Xu, B. 2017. The Politics of Compassion: The Sichuan Earthquake and Civic Engagement in China. Stanford: Stanford University Press.

Young, D. R. 2000. “Alternative Models of Government-Nonprofit Sector Relations: Theoretical and International Perspectives." Nonprofit and Voluntary Sector Quarterly 29 (1): 149-72.

Young, D. R. 2006. "Complementary, Supplementary, or Adversarial? Nonprofit-Government Relations." In Nonprofits \& Governments. Collaboration \& Conflict, edited by E. T. Boris, and C. E. Steuerle, 37-79. Washington D.C: The Urban Institute Press.

Zimmer, A. 1999. "Corporatism Revisited-The Legacy of History and the German Nonprofit Sector." Voluntas 10 (1): 37-49. 